Volume 7 Issue 2, June 2020

Nationally Accredited Journal,

Decree No. B/4130/E5/E5.2.1/2019

\title{
The Strength Of Legal Deed Auction Summary Of Burdened Of Confiscation Based On Regulation Of Finance Minister Number 27 / Pmk.06 / 2016 In The City Of Semarang
}

\begin{abstract}
Ferry Setiawan ${ }^{1}$, Yanto Risdianto ${ }^{2}$ and Soegianto ${ }^{3}$
Abstract. The purpose of this study was to: 1) To Know the Auction for Goods burdened Confiscation Based Finance Minister Regulation No. 27 / PMK.06 / 2016 in the city of Semarang. 2) To know the Power of Law Treatise Deed Auctions for Goods burdened Confiscation Based Finance Minister Regulation No. 27 / PMK.06 / 2016 in the city of Semarang. The data used in this study are primary data and secondary data and data that can support tertiary study, which was then analyzed by normative juridical method.

Based on the results of data analysis concluded that: 1) How the Auction of Goods Seized Burdened By Finance Minister Regulation Number 27 / PMK.6 / 2016 in Semarang. In the official auction assisted by guides who guilty of employees DJKN, the auction progresses No offers the winning auction is bidders who bid the highest. Each implementation of the auction will be charged Customs Auction accordance with government regulations governing the types and rates of non-tax state revenue. Payment of the auction price and Customs Auction shall be made in cash or check or checking account, no later than five (5) working days. In the case of submission of official documents of the auction must submit the original document of title or goods are auctioned off to the buyer or winning bidder no later than 1 (one) working day. Buyers must show proof of payment of the form and submit proof of deposit Tax on Acquisition of Land and Building If items such as land and buildings. 2) How the Legal Power of The Minutes of the Auction the Seized Goods Burdened By Finance Minister Regulation Number 27 / PMK.6 / 2016 in Semarang. Deed Auctions treatise consists of body deed, deed and leg mid deed which contains about the day, date, type of goods, address of the seller, as well as goods sold. Minutes of Deed Auctions is an authentic deed made by officials of the auction and use the laws and legislation so this auction treatise deed has permanent legal force if there are problems in the future.

Key Words: The Power of Law; the Deed of Auction; Goods Burdened Confiscation.
\end{abstract}

\section{Introduction}

Auction as an institution already known during the rule of the Dutch East Indies since 1998 when Vendu Reglement 1908 was published in the Government Gazette number 189 and Vendu Instruction published in the Government Gazette number 1908 Vendu Reglement 190. Since the enactment of the auction favored by the people for the auction of goods sold more numerous and varied, so buyers are free to choose the goods. In addition, the advantages of an auction system is that the auction buyers often get a cheaper price than the market price in general. Auction or public sale is a sale of goods made in front of the general public where the price of goods being offered to buyers at any time increases. ${ }^{4}$ Soemitro grace in his book quoted Polderman

\footnotetext{
1 Students Notary Semarang Sultan Agung Islamic University email ferrysetyawan565@gmail.com

${ }^{2}$ Student of Master of Law Program, Faculty of Law Universitas Islam Sultan Agung email risdianto 008@yahoo.co.id

${ }^{3}$ Public Notary / PPAT at Kudus Regency

${ }^{4}$ Salim HS, 2011, Perkembangan Hukum Jaminan di Indonesia, Jakarta: Rajawali Press, p. 239
} 
states that the public sale is a tool to hold a treaty or agreement the most by collecting enthusiasts. $^{5}$

Auctions in Indonesia is still an activity that is rarely used voluntarily by the community. People had a negative view about the auction because they have thought that the auction is always related to the execution of the court, although in reality it can not be denied because most auctions held as litigants. Auction institution in Indonesia not only as a trial execution, but the community is expected to utilize the institute to conduct voluntary auctions, auctions outside of the execution, as a way of selling goods other than sales by auction there are some benefits that will be enjoyed by the community.

Each of the auction, the official auction either the official auction of the class I or official auction class II should make the minutes of an auction that contains all the events that occur in the process of auction sales as proof authentication of the auction as set out in Article 77 of the Regulation of the Finance Minister Number 93 / PMK.06 / 2010, which reads: "officials who have conducted auctions auction shall make an official report called treatise auction auction".

Minutes of the auction ensuring legal certainty for the parties, since the minutes of the auction is an authentic act of purchasing a product through the sales process by auction, so that the evidence in the minutes of the auction property rights on the object of the auction would go to the winner of the auction, deed treatise auction is not only binds the seller and buyer with the auction item, but also officials who made the deed treatise auction the auction. Officials are also bound by the deed auction the auction treatise for an auction official public official because of the provisions of law which Vendu Reglement given the authority to make the deed of the minutes of the auction. Under these conditions, an auction official class I or class II auction officials in deed the minutes of the auction must be in accordance with the legislation in force.

Goods are burdened confiscation of goods belonging to the defendant disputed ownership status, or in accounts payable disputes or claims for compensation. If the plaintiff does not have strong evidence that the goods burdened arrest will not be given, this requirement is meant to no indiscriminate abuse that ultimately only an act of traces. Hence the request and filed a foreclosure is the owner of the goods themselves.

In this era, burdened stuff confiscated from various agencies, such goods can be from foreclosure. The origin of the goods seized from several foreclosure that court, tax seizure, confiscation customs and police seizure. The goods will then be in the auction through the nearest KPKNL then the result of the auction will be left entirely to the state.

Based on the description above, the writer interested to do research by lifting the title of " The Strength Of Legal Deed Auction Summary Of Burdened Of Confiscation Based On Regulation Of Finance Minister Number 27 / PMK.06 / 2016 In The City Of Semarang".

\section{Research methods}

The Method approach used in this study is a normative juridical approach. Normative research is legal research using secondary data sources or data obtained through

\footnotetext{
${ }^{5}$ Rahmat Soemitro, 2013, Peraturan dan Instruksi Lelang, Bandung: PT. Eresco, p. 106
} 
Volume 7 Issue 2, June 2020

Nationally Accredited Journal,

Decree No. B/4130/E5/E5.2.1/2019

library materials to examine the sources of literature relevant to the theme of research, including research on the principles of the law, sources of law, legal theory, books, legislation scientific theoretical as well as to analyze the issues discussed. ${ }^{6}$ That is to know the problems that arise in Deed Law of The Strength of Legal Deed Auction Summary of Burdened Of Confiscation Based On Regulation of Finance Minister Number 27 / PMK.06 / 2016 In The City Of Semarang.

\section{Results and Discussion}

\subsection{Auction for Goods Burdened Confiscation Based Finance Minister Regulation No. 27 / PMK.06 / 2016 in Semarang}

The auction is the sale of goods are open to the public at a price quote in writing and / or oral increased or decreased to achieve the highest price, which was preceded by the announcement of the auction.

\subsubsection{Implementation phase}

In the auction, auction officials may be assisted by a guide auction. Guides auction may come from inside the employee of DJKN or outside the employee of of DJKN, auction guides notified in writing by the seller or auction house to head KPKNL later than three (3) working days before the auction. In the implementation of the auction there are three (3) ways to offer: ${ }^{7}$

- Offer orally, increases or decreases.

- Offer in writing or

- Offer a written followed by oral, in which case the highest bid has not reached the limit value.

\subsubsection{Special stage}

Offer in writing auction conducted in the presence of bidders or without the presence of bidders. Auction offer in writing without the presence of bidders held by electronic mail (e-mail), by mail postal drum, or via the Internet either way open (open bidding) Nor way closed (closed bidding). Bidding can be conducted simultaneously in one (1) implementing the auction. Bidding through electronic mail (e-mail), postal mail or internet as a drum performance article 64 paragraph 3 may be submitted more than 1 (one) for each item, with the highest value of the offer is considered valid and rising. Auction bidding through electronic mail (email) drum post letter or the internet the way closed (closed bidding), opened at the time of exercise of the auction, by auction officials along with the seller and two (2) witnesses, each 1 (one) of KPKNL. Each participant of the auction must bid at least equal to the value of the limit in terms of the auction with a limit value is announced.

In the event that there are multiple bidders who submitted the highest offer verbal or written decreased by the same value and / or have reached or exceeded the limit value

\footnotetext{
6 Soerjono Soekanto and Sri Mamudji, 2010, Penelitian Hukum Normatif Suatu Tinjauan Singkat, Jakarta: Rajawali Press, p. 13-14.

7 Article 64 paragraph (1) Regulation of the Finance Minister No. 27 / PMK06 / 2016 On Implementation Guidelines for Auction
} 
in the auction using the value of the limit, the official authorized to sign the auction the buyer by means of: ${ }^{8}$

- Perform an advanced bidding only to bidders who bid the same, which is increasing orally or in writing by the consent of bidders concerned.

- Pass the draw among the bidders who bid the same if the provisions in a letter can not be implemented.

Each auction subject to Customs Auction accordance with government regulations governing the types and rates of non-tax state revenue prevailing at the Ministry of Finance. The cancellation of the plan of the auction conducted by the seller subject to Customs Auction Cancel On Demand Sales in Government Regulation governing the types and rates of non-tax state revenue prevailing at the Ministry of Finance, except Auction State / Region. Auction Top Bea Cancel Request Sales are paid by the seller, Bea Auction Cancel not be imposed on the auction cancellation of the determination or decision of a judicial or cancellation as an auction officials referred to in Article 28 paragraph (1), Article 30 and Article 31.

Auction officials certify the highest bidding has reached or exceeded the limit value as a buyer, in the implementation of the limit value use traditional auctions. In the event that there are bidders who bid the same top via electronic mail (email) or internet (in closed biding), officials certify Auction Bidder whose bid is accepted first as a buyer. Buyers are prohibited from taking or control of goods bought before the auction payment obligations and taxes or other lawful appropriate laws. Bidders who acts for another person or legal entity or entities must submit a power of attorney that enough to the official auction by enclosing a photocopy of identity card (ID) or Driving License (SIM) or Passport endorser and endorsee by showing the original. Endorsee not to request more than one authorization for the same goods.

\subsubsection{Payments stage}

Payment of the auction price and customs auction should be made in cash or a check or checking account, no later than five (5) business days after the auction implementation. Full payment by the buyer Auction conducted through KPKNL account within 5 (five) working days. Every payment of the auction by the purchaser must be made of receipts or proof of payment by the Treasurer Admission KPKNL / or Officer Auction Class I. In the event that the buyer fails to pay the auction payment as stipulated in article 79 on the next working day, officials had to cancel the auction as a buyer with endorsement make a statement of cancellation. Depositing the net proceeds of the auction on auction items State / Regional and the corresponding items of legislation should be paid in cash to the Country / Region, made at least 1 (one) working days after payment is received by the treasurer reception KPKNL. In the event that the net result of the auction as referred to in Article 82, paragraph (1) deposited or delivered to the seller at the request of the seller, deposit or delivery to the seller made no later than one business day after payment is received by the treasurer reception KPKNL, henceforth must be paid immediately to the Treasury Country by Seller. Deposit Auction Customs and Income Tax (pph) to the State Treasury at least 1 (one) working days after payment is received by the Treasurer Admission KPKNL or Auctioneer. The net result of the auction in addition to the auction as aforesaid, shall

\footnotetext{
${ }^{8}$ Article 68 Regulation of the Finance Minister No. 27 / PMK06 / 2016 On Implementation Guidelines for Auction
} 
Volume 7 Issue 2, June 2020

Nationally Accredited Journal,

Decree No. B/4130/E5/E5.2.1/2019

be paid to the seller no later than three (3) working days after payment is received by the Treasurer Admission KPKNL or Auctioneer.

\subsubsection{Document Delivery Phase}

In terms of delivery of document, sellers submit original documents of ownership to the official auction as referred to in Article 21, paragraph 3, officials of the auction must submit the original documents of title and / or things that auctioned, and buyer no later than 1 (one) working days after the buyer show a receipt or proof of payment of, and submit proof of deposit Tax on Acquisition of land and building (BPHTB) if items are auctioned in the form of land and buildings. If the seller does not submit the original document of ownership as meant in Article 21 paragraph (4) to the official auction, Sellers must submit the original document of ownership and / or goods are auctioned to the buyer, not later than 1 (one) working days after the buyer show invoices meters or proof repayment.

\subsubsection{Preparation Treatise of Deed Auctions Phase}

Minutes of Deed Auctions is a news event made implementation auction officials who are authentic and have certificates proving perfect in the eyes of the law. ${ }^{9}$ Made to be justified in the future if there is a legal problem.

\subsection{The Strength of Legal Deed Auction Summary of Burdened Of Confiscation Based On Regulation of Finance Minister Number 27 / PMK.06 / 2016 In The City Of Semarang}

In the Auction officials who carry out the auction shall make minutes of the auction. Minutes of the minutes of the auction is the auction implementation made by the Official Auction is authentic act and have the power of proving perfect. ${ }^{10}$ In deed the minutes of the auction consists of:

- The head

- The body and

- The legs

Section Head of the Minutes of the Auction shall at least contain: ${ }^{11}$

- Day, date and time of the auction is written with letters and numbers

- Full name and domicile of officials Auction

- Number and date of appointment decisions Officials Auction

- Number and date of a special assignment for class 1 officer

- Full name, occupation, and the position of the seller

- Number or date of the Application for auction

- Points the auction

- The nature of the goods being tendered and the reason these items auctioned

\footnotetext{
${ }^{9}$ Article (1) The Finance Minister Regulation No. 27 / PMK.06 / 2016 On Implementation Guidelines Auction

${ }^{10}$ Rachmadi Usman, 2016, Hukum Lelang, Jakarta: Sinar Grafika, p. 159

${ }^{11}$ Article (86) Finance Minister Regulation No. 27 / PMK.06 / 2016 On Implementation

Guidelines Auction
} 
- In terms of the auction objects in the form of goods not moving in the form of land or land and buildings should be mentioned:

- Status rights or other papers that explain the evidence of ownership name

- Number and date of SKT / SKPT of the land office

- Other information that burden if there

- Auction in the form of goods moving object must be mentioned amount, type, and specification of goods

- How to auction announcements that have been implemented by the seller

- How bidding, and

- Terms and conditions of auction

Minutes of the body section shall contain at least auctions ${ }^{12}$

- The number of deals and legitimate incoming auction

- Name / brand / type / types / and quantity of goods to be auctioned

- Name, occupation and address of the buyer on his own behalf or as the authority on behalf of the legal entity / entities / others.

- Bank creditors as a buyer for the person or legal entity / entities designated by name in terms of the creditor banks as an auction buyers.

- Auction price with numbers and letters

- List of goods sold and detained along with the price, the name and address of the Bidder highest bidders

The foot of the Minutes of the Auction shall at least contain:

- The number of items offered or tendered with lift and letters

- The number of items sold or sold with numbers and letters

- Total price of goods that have been sold with numbers and letters

- Total price of goods stuck with numbers and letters

- The number of documents or letters annexed to the auction with numbers and letters

- The number of changes made (note, additionally, graffiti with his successor) and no changes are written with numbers and letters

- Auction officials bunches of hand and power seller or the seller, in the case of auction items or signature move Officials Auction, Seller and buyer power or the power of buyers, the goods do not move

- Signature of witnesses to an auction by bidding without the presence of bidders via electronic mail (e-mail), mail or internet drum (closed bidding)

Minutes of the auction made using Indonesian, in every treatise auction given by serial number. Auction officials first class in the form of certificates issued treatise authentic deed auction must meet the elements as represented authentic act is governed by Article 1868 and 1870 of the Civil Code. For class 1 auction officials responsible for the authenticity of the Deed of Minutes of Auction made.

Deed minutes of the auction is an authentic act, in which an authentic deed must be made based on the form that has been set by the Act. ${ }^{13}$ Auction treatise called authentic act is if the minutes of the auction fulfill the elements as mentioned in Article 1868 of the Civil Code which states "An authentic deed is a deed in the form prescribed

12 Article (87) Finance Minister Regulation No. 27 / PMK.06 / 2016 On Implementation Guidelines Auction

${ }^{13}$ Article (1) of paragraph (1) Regulation of the Finance Minister No. 27 / PMK06 / 2016 On Implementation Guidelines for Auction 
Volume 7 Issue 2, June 2020

Nationally Accredited Journal, Decree No. B/4130/E5/E5.2.1/2019

by the Act, made by or before public officials power to the place where the deed made

". Elements treatise auction is an authentic act, namely:

- It shall be made by or in the presence of a public official

- It shall be made in the form prescribed by law

- The public servant by or before whom the deed was made, should have the authority to make such deed. ${ }^{14}$

Thus, if the elements of the minutes of the auction as an authentic act have been met, then the minutes of the auction can be used as evidence are perfect for parties.

\section{Closing}

\subsection{Conclusion}

- In the official auction assisted by guides who guilty of employees DJKN, the auction progresses No offers the winning auction is bidders who bid the highest. Each implementation of the auction will be charged Customs Auction appropriate government regulations and tariff types of non-tax state revenue. Payment of the auction price and Customs Auction shall be made in cash or check or checking account, no later than five (5) working days. In the case of submission of official documents of the auction must submit the original document of title or goods are auctioned off to the buyer or winning bidder no later than 1 (one) working day. Buyers must show proof of payment of the form and submit proof of deposit Tax on Acquisition of Land and Building If items such as land and buildings.

- Deed Auctions treatise consists of body deed, deed and leg mid deed which contains about the day, date, type of goods, address of the seller, as well as goods sold. Minutes of Deed Auctions is an authentic deed made by officials of the auction and use the laws and legislation so this auction treatise deed has permanent legal force if there are problems in the future.

\subsection{Suggestion}

- Implementation auction according to finance minister regulation number 27 / PMK.06 / 2016 quite well but it is good in terms of the delivery of official documents from the seller or the auction to the buyer or winning bidder should be given immediately upon the buyer to show proof of receipt of payment.

- Legally enforceable deed treatise existing auction should be strengthened further for the future, that the public will be more interested in using the purchase in the form of an auction.

\section{References}

\section{Book}

[1] Habib Adjie, 2011, Kebatalan Dan Pembatalan Akta Notaris, Bandung: PT. Refika Aditama

[2] Rahmat Soemitro, 2013, Peraturan dan Instruksi Lelang, Bandung: PT. Eresco

\footnotetext{
${ }^{14}$ Habib Adjie, 2011, Kebatalan Dan Pembatalan Akta Notaris, Bandung: PT Refika Aditama, p 6.
} 
[3] Rachmadi Usman, 2016, Hukum Lelang, Jakarta: Sinar Grafika

[4] Salim HS, 2011, Perkembangan Hukum Jaminan di Indonesia, Jakarta: Rajawali Press

[5] Soerjono Soekanto and Sri Mamudji 2010, Penelitian Hukum Normatif Suatu Tinjauan Singkat, Jakarta: Pres Rajawali

\section{Legislation}

[1] Article (1) of paragraph (1) Regulation of the Finance Minister No. 27 / PMK06 / 2016 On Implementation Guidelines for Auction

[2] Article 64 paragraph (1) Regulation of the Finance Minister No. 27 / PMK06 / 2016 On Implementation Guidelines for Auction

[3] Article (86) Finance Minister Regulation No. 27 / PMK.06 / 2016 On Implementation Guidelines Auction

[4] Article (87) Finance Minister Regulation No. 27 / PMK.06 / 2016 On Implementation Guidelines Auction

[5] Book of Civil Law (Civil Code) 